\title{
Gene Promoter Variation of Phosphoglycerate Kinase, a Glucose Metabolism Enzyme, is a Biomarker for Selection of Disease-resistant Sea Squirt, Halocynthia Roretzi
}

\author{
Hyun Kook Cho', Young Baek Hur ${ }^{2}$ and Jae Hun Cheong ${ }^{3}$ * \\ ${ }^{1}$ Biotechndogy Research Center, National Fisheries Research and Development Institute, Gijang-gun, Busan 619-902, Korea \\ ${ }^{2}$ Aquaculture Environment Institute, Tongyoung 650-943, Korea \\ ${ }^{3}$ Department of Molecular Biology, Pusan National University, Busan 609-735, Korea
}

Received January 7, 2013 /Revised February 20, 2013 /Accepted February 21, 2013

\begin{abstract}
The sea squirt, Halocynthia roretzi, has experienced mass mortality due to softness syndrome. The identification of disease-induced genes can provide insights into the development of this syndrome. To identify the genes, we performed differentially expressed gene (DEG) analysis. The expression of the phosphoglycerate kinase (HrPGK) gene was significantly decreased in diseased sea squirts compared to normal ones. We confirmed the result of the DEG analysis through RT-PCR and real-time PCR. In addition, we detected single nucleotide polymorphisms at position -106 (A/T) and -254 (G/T) in the $\operatorname{HrPGK}$ gene promoter by genotyping analysis. At the -106 site of the HrPGK gene, the frequency of the AA allele in disease-resistant sea squirts was about two-fold higher than that of sensitive ones, and the frequency of the TT allele in the disease-resistant sea squirts was about six-fold lower. At the -254 site of the HrPGK gene, the frequency of the GT and the GG allele was approximately two-fold higher and two-fold lower, respectively, in the disease-resistant sea squirts compared to the disease-sensitive ones. Analysis of the relationship between the genotypic variation at the -106/-254 promoter and the expression of $H r P G K$ mRNA showed that $H r P G K$ mRNA expression was higher in the -106/-254 AA/GT genotype samples than in the -106/254 TT/GG genotype ones. These results show that sea squirts harboring the AA/GT genotype may have more resistance to mortality than the sea squirts with other genotypes.
\end{abstract}

Key words : Halocynthia roretzi, phosphoglycerate kinase, polymorphism, sea squirt, softness syndrome

\section{Introduction}

The sea squirt, Halocynthia roretzi, cultured commercially in eastern Asia countries has shown mass mortality during the last 20 years. Because the tunics of the diseased ascidians are always thinner and softer than those of healthy individuals, the soft tunic is the most remarkable clinical sign of the disease. Although there is debate regarding the disease-causing agent, it has not yet been identified $[1,4]$. The tunic is a leathery or gelatinous matrix that entirely covers the epidermis of ascidians. This tissue is unique in metazoans; the main component of the matrix is cellulose and free cells (called tunic cells) are distributed in the tunic matrix (i.e. outside the epidermis). The tunic is harder when

\footnotetext{
*Corresponding author

Tel : +82-51-510-2277, Fax : +82-51-513-9258

E-mail : molecule85@pusan.ac.kr

This is an Open-Access article distributed under the terms of the Creative Commons Attribution Non-Commercial License (http://creativecommons.org/licenses/by-nc/3.0) which permits unrestricted non-commercial use, distribution, and reproduction in any medium, provided the original work is properly cited.
}

the tunic fibres are more densely packed. As the tunic is the outermost barrier between the internal body and the exterior environment, a decline in tunic function would be lethal for the animals. The most remarkable difference between intact and diseased tunics is the bundles of tunic fibres composing the tunic matrix. The tunic fibres consist of cellulose fibrils linked with polysaccharides and proteins. The thick bundles interlace to form a firm matrix in intact tunics, whereas the tunic fibres do not form thick bundles in soft tunics. This would directly cause the difference in tunic hardness between intact and diseased tunics. In serious cases the tunic tears, and as a consequence the ascidian dies.

Although researchers have proposed several possible syndrome-inducing factors including environmental pollutants, heavy metal ions, microbial or parasite infection, and abnormal temperature changes, the causes remain poorly understood. Disease development causes change in intracellular or intercellular, tissue, organ, subsequently organism level. The environmental change regulates protein expression and deregulated protein can aggravate the disease. The identification of disease-specific genes would provide 
insights into understanding the softness syndrome development. To identify the molecular basis of the disease-causing proteins, it would be of interest to identify and perform detailed characterization of differentially expressed genes (DEG).

As revealed by DEG analysis from previous study [3], the expression of some genes was reduced, whereas the expression of other genes was increased during the progression of softness syndrome. Among differentially expressed genes, we selected a gene for phosphoglycerate kinase (HrPGK) as a candidate of softness syndrome, and obtained a full-length cDNA sequence of the $H r P G K$ through 5 -RACE. The results of real-time PCR demonstrated the differential expression of the HrPGK gene in diseased sea squirts. In this study, we describe the promoter polymorphisms of $H r P G K$, and elucidate the relationship between polymorphic variations of the HrPGK promoter and the differential expression of the HrPGK gene in the development of softness syndrome of sea squirt.

\section{Materials and Methods}

\section{Field survey protocols}

Sampling was conducted at a marine sea squirt farm in the Tongyoung Bay of the Southern Ocean, Korea. Collections were conducted via SCUBA diving from hanging cultures. The samples including normal and diseased sea squirts, were collected from March to June of 2006 in each month. Total 206 different collected samples (normal, 113; sensitive, 23; resistant, 70) were directly transferred to the laboratory and were prepared with each organ, namely the hepatopancreas, intestine, gonad including body muscles, and tunic. The organ pieces were treated with liquid nitrogen and stored in a deep freezer $\left(-80^{\circ} \mathrm{C}\right)$ until use.

\section{Reverse transcription- polymerase chain reaction}

Total RNA was prepared from hepatopancreas using Trizol reagent (Invitrogen) in accordance with the manufacturer's instructions. One microgram of total RNA was treated with DNase, and cDNA was synthesized using the Advantage RT-for-PCR kit (BD Biosciences, CA). The specific primers used for the target genes were: PGK-F: 5'-AGG AAG TGG CAT TCC AGA AGG-3' and PGK-R: 5' - TCG AAG GAA CCC ATG GCG ATT-3; $\beta$-actin, forward: 5'-GTA CGT TGC CAT TCA AGC TG-3' and reverse: 5'-AGT CCT TAC GGA TAT CGA CG-3', which were used for the verification of the quality and the size of the genes in the library. $\beta$-actin is used as loading control.

\section{Real-time PCR}

The assay for HrPGK in normal and diseased sea squirts was conducted using a Light Cycler system with SYBR Green I (Roche Diagnostics). Serial diluted samples containing $2 \times 10^{-3}-2 \times 10^{-6}$ ng of a cloned fragment of HrPGK were used to quantify the absolute expression level of PGK in normal and diseased sea squirts. The PGK level was normalized relative to the $\beta$-actin mRNA level. The remaining process was described previously [3].

\section{Genomic walking}

Promoter region of $H r P G K$ was obtained using GenomeWalker ${ }^{\mathrm{TM}}$ Universal Kit (Clontech). Briefly, the primary PCR uses the outer adaptor primer (AP1) provided in the kit and an outer, gene-specific primer (PGK GW1; 5'-AAC GAC ATA GCG AGA GTA TCA CCC-3'). The primary PCR mixture is then diluted and used as a template for a secondary or nested PCR with the nested adaptor primer (AP2) and a nested gene specific primer (PGK GW2, 5'-TTG TAG AAC AGA TCT AAA TAA TGG CT-3'). Major PCR product that was obtained through gel extraction was cloned into the pGEM-T easy vector (Promega). DNA sequencing was conducted with M13 Forward/Reverse primers using an ABI 3100 automated sequencer.

\section{Sequence analysis}

The predicting of transcription factor binding sites in PGK promoter sequences were analyzed in Transcription Element Search System (TESS, http://www.cbil.upenn.edu/cgi-bin/ tess/tess) web site.

\section{Single nucleotide polymorphisms (SNPS) analysis} and Statistical Analysis

Using normal sea squirts (96 samples), PCR was conducted using specific primers (Forward: 5'-GTG GTA ACT CAT CGG AAT CTG T-3', Reverse: 5'-AAC GAC ATA GCG AGA GTA TCA CCC-3'). After obtaining the 380-bp PCR product, direct sequencing was conducted using the reverse primer. Using SeqMan NGen Ver 1.1 program, analysis of PGK promoter SNPs was performed with the sequences. In addition, 20 disease-resistive and 43 sensitive sea squirts, which were collected in April 2008, within a population were analyzed to identify genotype frequency at SNP sites. 
Statistical analyses were carried out by chi-square test as appropriate. $P$ value of $<0.01$ was considered significant.

\section{Results}

Differentially expressed genes in a sea squirt with softness syndrome

In order to identify genes that are specifically or predominantly expressed in the tissues of diseased sea squirts, we compared the total different mRNA expression profiles of the normal and diseased sea squirts through DEG analysis in previous study [2]. In human, PGK deficiency affects glycogen synthesis [11] and is involved in muscle disease, which may be associated with chronic hemolysis $[6,10]$. Because the muscle disease is the main symptoms in the diseased sea squirts, we selected $P G K$ gene as a candidate of softness syndrome. To further confirm the results of DEG analysis, semi-quantitative RT-PCR were performed. The results revealed that the expression of the HrPGK gene was lower in tissue of diseased sea squirts than in that of normal sea squirts and was consistent with the result of the DEG analysis (Fig. 1A). In addition, fluorescence-monitored quantitative real-time PCR was employed to quantitatively analyze the expression of HrPGK. As shown in Fig. 1B, the ex- pression of the HrPGK gene decreased in the diseased sea squirts (3.18E-0.5 ng/10 ng total RNA) compared to normal ones (5.00E-0.6 ng/10 ng total RNA).

\section{Polymorphisms and allele frequency on HrPGK promoter of each of the populations}

Since the proximal promoter sequences play an important roles in regulation of gene expression, the proximal promoter sequences of the HrPGK gene were investigated using the specific primers (Fig. 2) Polymorphisms were detected at $-106(\mathrm{~A} / \mathrm{T})$ and $-254(\mathrm{G} / \mathrm{T})$ position in the HrPGK promoter of normal sea squirts by performing genotyping analysis (Fig. 2). Then, we carried out genotyping of disease-sensitive and -resistive sea squirts and compared polymorphism frequency between them. At -106 site of the HrPGK, while the AA allele frequency of disease-resistive sea squirts was higher about two folds than that of disease-sensitive ones, the TT allele frequency of those was lower about 6 folds. The AT allele frequency showed a similar value between them (Table 1). At -254 site of the HrPGK, the GT and GG allele frequency was higher and lower about 2 fold in disease-resistive sea squirts than in disease-sensitive ones, respectively. The frequencies in disease-sensitive sea squirts showed the opposite trend com-
A

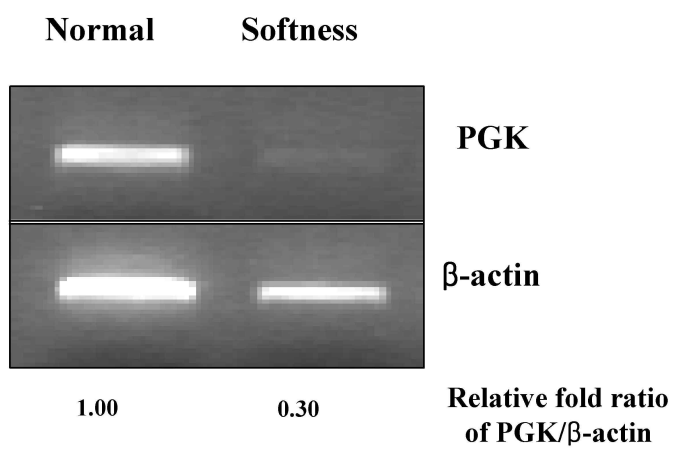

B

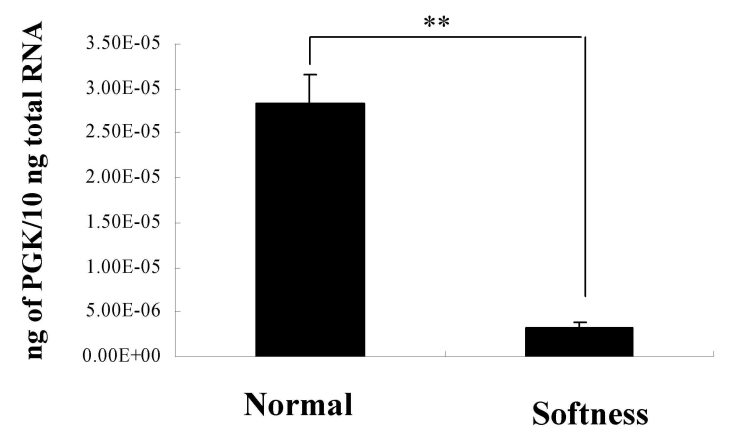

Fig. 1. Differential expression of the HrPGK in sea squirt with softness syndrome. (A) Comparison of the PGK expression pattern in the disease developing sea squirts via semi-quantitative RT-PCR. $\beta$-actin is used as loading control. Data from RT-PCR were quantified and normalized relative to the $\beta$-actin mRNA level using ImageJ version $1.35 \mathrm{~d}$ (NIH Image). (B) Absolute expression levels (ng of PGK per $10 \mathrm{ng}$ total RNA) of PGK in disease-sensitive and normal Halocynthia roretzi. The number of sample is five in each group. ${ }^{* *} p<0.01$ compared with softness.

Table 1. Allele frequency (\%) of the HrPGK promoter -106 SNP site

\begin{tabular}{ccccc}
\hline & TT & AT & AA & $p$ value* \\
\hline Normal & 25 & 47 & 28 & $p<0.001$ \\
Sensitive & 37 & 42 & 21 & 47 \\
Resistant & 6 & 47 & 47 & \\
\hline
\end{tabular}

${ }^{*}$ Chi-square $=33.2$ with 4 degrees of freedom 


\begin{tabular}{|c|c|c|}
\hline-1096 & AAATTACGCAAATCTACCATGCCGAAATACACCAGTCATATCCAGATATACAGAAACGAAGAACTGGATGATGAATCTGATAAACCCTTCTGTCTGAAAGAGAAAGAAGATCTTCGAAC & G -977 \\
\hline-976 & GTTGAGATCATGTCGAACATCTGATTGAATCGATGAGAAGAATAAAATCAAAATAGGACTTCTTTCCATTTACATAAAAGCATATAAAGCCATGGTTCTTGTAGTAGGAGAAAGAAGGA & T -857 \\
\hline-856 & GCGTGTGGAAACATCTTCTACCAATAAACAAGCTTCTATAACTGGCTACATTACTCAAAGTGTGTGTTTTTATACTCTTATCATGATTACTGGAATGCAGTTAATTGGAACTGTGTTTT & T -737 \\
\hline-736 & GATACATTTATGTGAGTCATTAATTGTCGCTGTTATTATCTGGACTTTTTTTTCACTTCCACAATTTTGCATTGCACATTCTCGCCGCTATTATGTACAAGGCTAAAAATAAATTTTA & $T-617$ \\
\hline-616 & ACTTGTATAGAGGCCGCAATCCTCATGTCGAGGACCTCCGCTGGTCTATTTAGAGGTCAAGTCATTTTAGACATCCATGCGTGACAAAAACCAACTCGACATTGAAGAGTACTACCGAG & A -497 \\
\hline-496 & TGTATTACAACCGTCAGTCTTGATTACTTTCTTTTATTTAGGAAGCAGTATGTGGATAAGCCTAAATAATAAAAGAAAACGAAACCCTAACACTGATGTATGCATATTAGCAAGACTTA & A -377 \\
\hline-376 & $\begin{array}{l}\text { TACGAATCAGAGCTACGAATGTACGAAAAGTAAGTGAAATATGTGAATGATATTAATTCAGAACGGTAAGGCGGTTCTTGATTTGT } \\
*\end{array}$ & T -257 \\
\hline-256 & $\begin{array}{l}\text { CTGCAGGAAATGACATAACAAAACTTTATATTTATCCTTTTACTTTACCGTGACGTTTTCAATCTGGTAATGCATTAGTAATTGCATACTTGGCGACACATATTGCATAATACATGAG } \\
\star *\end{array}$ & A -137 \\
\hline-136 & AGTATGACGTACCCGATAGTGATGATTTACTCAAAGTCAAACGCTACGCACGTGATGAAAGCATGAAAAGTGATCACAGTGGTGTCCGACCGCACCTAGTAAATTATAAATACETTATT & C - 17 \\
\hline 6 & GGGTGATACTCTCGCTA GT GT GA & 104 \\
\hline
\end{tabular}

Fig. 2. Nucleotide sequence of the $5^{\prime}$-flanking promoter region of the $\operatorname{Hr} P G K$ gene. Sequence A in the second box is a putative transcription start site. The TATA box and start codon of the HrPGK gene are located 27 to $32 \mathrm{nt}$ upstream and $82 \mathrm{nt}$ downstream from the putative transcription start site, respectively. Specific primer for promoter SNPs of the HrPGK gene are underlined. The SNPs site of the HrPGK promoter is represented by an asterisk $\left(^{*}\right)$.

Table 2. Allele frequency (\%) of the HrPGK promoter -254 SNP site

\begin{tabular}{ccccc}
\hline & TT & GT & GG & $p$ value* \\
\hline Normal & 8 & 33 & 59 & $p=0.001$ \\
Sensitive & 9 & 26 & 65 & 37 \\
Resistant & 10 & 53 & & \\
\hline
\end{tabular}

${ }^{*}$ Chi-square $=18.8$ with 4 degrees of freedom

pared to those of disease-resistive ones. The TT allele frequency showed a similar value between them (Table 2). To analyze statistical data, we carried out chi-square test for allele frequency between each of the groups. All of the scores indicate statistical significance $(p<0.01)$. These results show that sea squirts harboring the AA/GT genotype may have more resistance to the disease than the sea squirts with genotype of the others.

\section{Effect of genotype variation on HrPGK gene transcription}

In order to further assess the relationship between genotypic variation at the $-106 /-254$ promoter and the expression of HrPGK mRNA, we conducted RT-PCR and real-time PCR using the same samples. As predicted, HrPGK mRNA expression was higher in the -106/-254 AA/GT genotype samples than in the $-106 / 254$ TT/GG genotype ones (Fig. 3A and $3 \mathrm{~B})$. For the molecular regulation of $H r P G K$ gene tran- scription, the specific transcription factors should bind to their cognate-recognizing DNA elements within the promoter region of HrPGK Using Transcription Element Search Software (http://www.cbil.upenn.edu/cgi-bin/tess/tess), we compared tentative transcription factors which are capable of binding to the HrPGK gene promoter what the genotype of the $-106 /-254$ site is $\mathrm{A} / \mathrm{T}$ or $\mathrm{T} / \mathrm{G}$, respectively (Fig. $3 C)$. The candidates for transcription factors at the -106 or -254 site were identified as activator protein-1 (AP-1) or nuclear factor of activated T-cells (NF-AT), respectively. The difference of transcription factor's binding ability which can recognize each sequence in the sites might result in abnormal gene transcription and protein levels of HrPGK, explaining the induction of sea squirt mortality. These results suggest that sea squirts with the -106/-254 AA/GT genotype in the HrPGK promoter exhibit more abundant HrPGK production in the tissues, and may also give a tendency toward 
$\mathbf{A}$

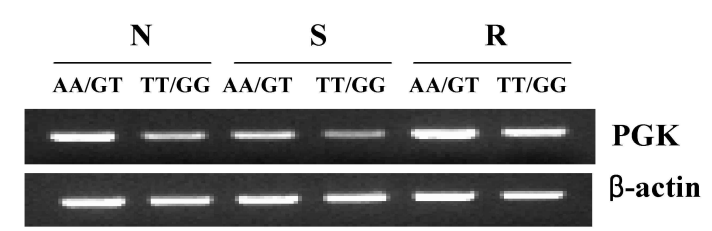

B

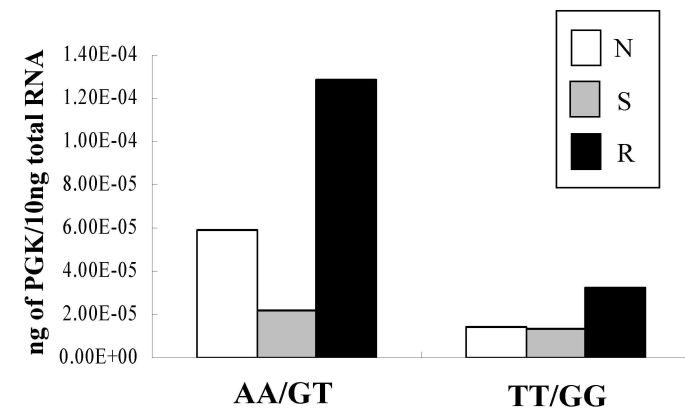

C

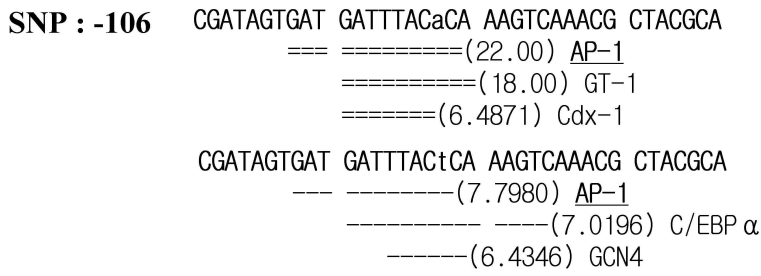

SNP : -254 TGTGCAAACG TTTTTCTtCA GGAAATGACA TAACAAA

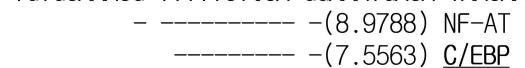

TGTGCAAACG TTTTTCTgCA GGAAATGACA TAACAAA

$======(6.5244) \mathrm{Cdx}-1$

-------(7.2198) GATA-1

--- ------- (7.1624) NF-AT

Fig. 3. The genotype of promoter SNP and HrPGK expression. (A) Relative expression level of HrPGK by genotype difference. (B) Absolute expression levels (ng of PGK per $10 \mathrm{ng}$ total RNA) of HrPGK by genotype difference. AA/GT and TT/GG, genotypes of the site with polymorphism. (C) The responsive elements of differential transcription factors at the polymorphic -106 and $-254 \mathrm{bp}$ sites of the HrPGK gene promoter. This study was conducted via the application of the transcription element search system (TESS), provided by the University of Pennsylvania.

mortality resistance in an aquaculture environment.

\section{Discussion}

The identification of disease-specific genes would provide us with great insights into the mechanisms underlying disease development. Through DEGs analysis, MMP, Ferritin, Endophilin-B1, and etc. were up-regulated in the disease-sensitive sea squirts, but PGK, phosphoenolpyruvate carboxykinase, and etc. were down-regulated (Supplement Table 1). Over-expressed MMP might influence the extracellular environment by resolving the extracellular matrix. PGK deficiency affects glycogen synthesis [11] and is involved in muscle disease $[6,10]$. Many studies have reported correlation between human disease and metabolic genes [7-9]. Thus, because glycogen is the principal ingredient of sea squirt muscle, the inhibition of glycogen synthesis may induce softness syndrome in the sea squirt. The hypomorphic HrPGK may contribute to the development of softness syndrome in the sea squirt by inhibiting the synthesis of tunicine, typical animal cellulose that comprises the sea squirt's tunic and by weakening the muscle. Therefore, reduced HrPGK levels in the sea squirt may result in a deficiency in major components for the functional and structural intensity of the muscle and tunic.
We do still not know precisely how the disease occurs in sea squirts evidencing softness syndrome in the tunic and tissues. Disease-resistive sea squirts evidencing the -106/-254 AA/GT genotype of HrPGK may express a greater quantity amount of PGK protein, thus providing disease-resistive activity in the presence of disease-causing factors, such as parasitic infection and environmental factors, associated with sea squirt mortality.

In general, transcription of genes was regulated by transcription factors, which bind to their cognate-recognizing DNA elements within the promoter region. AP-1 that may bind PGK promoter -106 site is a transcriptional factor comprising members of the Fos family (c-Fos, FosB, Fra-1, and Fra-2) and the Jun family (c-Jun, JunB, and JunD) [12]. The transcription factors c-Fos and c-Jun are known to be involved in cellular proliferation and transformation [13], and are activated by high levels of $\mathrm{NaCl}[5,14]$. By performing luciferase assay using HrPGK promoters with other genotypes, correlation between gene expression and promoter genotype variants of HrPGK will be known.

A final objective of our study was to assess the possibility of selective breeding of sea squirts with resistance against the disease. These results will be of great importance in the selection of disease-resistive sea squirts. In service of this goal, we have attempted to apply this genotypic difference 
Supplement Table 1. Differentially expressed genes in normal and abnormal sea squirts

\begin{tabular}{cccl}
\hline $\begin{array}{c}\text { DEG } \\
\text { No. }\end{array}$ & $\begin{array}{c}\text { Accession } \\
\text { No.* }\end{array}$ & $\begin{array}{l}\text { Normal/ } \\
\text { Abnormal }\end{array}$ & \\
\hline DEG 3 & JK044146 & Abnormal & similar to Transgelin-3 (Neuronal protein NP25) (Neuronal protein 22) (NP22) [Ciona intestinalis] \\
DEG 11 & JK044147 & Abnormal & Zinc metalloproteinase nas-13 [Bacillus thuringiensis serovar huazhongensis BGSC 4BD1] \\
DEG 15 & JK044148 & Abnormal & No significant similarity found \\
DEG 16 & JK044149 & Normal & similar to phosphoglycerate kinase [Ciona intestinalis] \\
DEG 18 & JK044150 & Abnormal & hypothetical protein BRAFLDRAFT_205068 [Branchiostoma floridae] \\
DEG 22 & JK044151 & Abnormal & rCG25732, isoform CRA_c [Rattus norvegicus] \\
DEG 23 & JK044152 & Abnormal & No significant similarity found \\
DEG 24 & JK044153 & Abnormal & No significant similarity found \\
DEG 25 & JK044154 & Normal & Phosphoenolpyruvate carboxykinase [Acanthopagrus schlegelii] \\
DEG 49 & JK044155 & Abnormal & similar to Slc38a4 protein [Ciona intestinalis] \\
DEG 54 & JK044156 & Abnormal & similar to cat eye syndrome chromosome region, candidate 5 homolog [Ciona intestinalis] \\
DEG 57 & JK044157 & Normal & similar to Cysteine conjugate-beta lyase 2, partial [Ciona intestinalis] \\
DEG 70 & JK044158 & Abnormal & similar to MGC79571 protein [Ciona intestinalis] \\
DEG 84 & JK044159 & Abnormal & similar to ferritin, heavy polypeptide 1 [Ciona intestinalis] \\
DEG 88 & JK044160 & Abnormal & Wzy [Shigella boydii CDC 3083-94] \\
DEG 90 & JK044161 & Abnormal & Zinc metalloprotease [Fusobacterium sp. 7_1] \\
DEG 110 JK044162 & Abnormal & Endophilin-B1 [Dicentrarchus labrax] \\
DEG 113 JK044163 & Normal & putative porin-like [Saccoglossus kowalevskii] \\
\hline
\end{tabular}

* GenBank dbEST accession number

\# Normal, it is over-expressed in normal organism; Abnormal, it is over-expressed in dying organism

at aquaculture facilities. First, we selected the possible disease-resistive seedlings using the SNP pattern described in this study. We then transplanted several genotype seedlings in aquaculture applications in several different environments. After determining the survival and mortality results for the sea squirts, we will analyze and select the resistive sea squirts, subsequently providing seedlings from the resistive ones for the breeders to use in sea squirt aquaculture.

\section{Acknowlegments}

We thank everyone at the Aquaculture Environment Institute for providing the sea squirt samples. This work was supported by a 2-Year Research Grant of Pusan National University.

\section{References}

1. Azumi, K., Nakamura, S., Kitamura, S., Jung, S. J., Kanehira, K., Iwata, H., Tanabe, S. and Suzuki, S. 2007. Accumulation of organotin compounds and marine birnavirus detection in Korean ascidians. Fish Sci 73, 263-269.

2. Breathnach, R. and Chambon, P. 1981. Organization and expression of eucaryotic split genes coding for proteins. Annu Rev Biochem 50, 349-383.
3. Burighel, P. and Cloney, R. A. 1997. Microscopic Anatomy of Invertebrates, Volume 15: Hemichordata, Chaetognatha, and the Invertebrate Chordates, pp. 221-347. Wiley-Liss, New York City, NY, USA.

4. Cho, H. K., Nam, B. H., Kong, H. J., Han, H. S., Hur, Y. B., Choi, T. J., Choi, Y. H., Kim, W. J. and Cheong, J. 2008. Identification of softness syndrome-associated candidate genes and DNA sequence variation in the sea squirt, Halocynthia roretzi. Mar Biotechnol (NY) 10, 447-456.

5. Choi, D. L., Jee, B. Y., Choi, H. J., Hwang, J. Y., Kim, J. W. and Berthe, F. C. J. 2006. First report on histology and ultrastructure of an intrahemocytic paramyxean parasite (IPP) from tunicate Halocynthia roretzi in Korea. Dis Aquat Organ 72, 65-69.

6. Cohen, D. M., Wasserman, J. C. and Gullans, S. R. 1991. Immediate early gene and HSP70 expression in hyperosmotic stress in MDCK cells. Am J Physiol 261, C594-C601

7. Corden, J., Wasylyk, B., Buchwalder, A., Sassone-Corsi, P., Kedinger, C. and Chambon, P. 1980. Promoter sequences of eukaryotic protein-coding genes. Science 209, 1406-1414.

8. Fujii, H., Kanno, H., Hirono, A., Shiomura, T. and Miwa, S. 1992. A single amino acid substitution (157 Gly $\rightarrow$ Val) in a phosphoglycerate kinase variant (PGK Shizuoka) associated with chronic hemolysis and myoglobinuria. Blood 79, $1582-1585$.

9. Hultmark, D., Klemenz, R. and Gehring, W. J. 1986. Translational and transcriptional control elements in the untranslated leader of the heat-shock gene hsp22. Cell 44, 429-438. 
10. Kadonaga, J. T. 2002. The DPE, a core promoter element for transcription by RNA polymerase II. Exp Mol Med 34, 259-264.

11. Karnsakul, W., Gillespie, S., Skitarelic, K. and Hummel, M. 2010. Obesity and reversed growth retardation in a child with type Ia glycogen storage disease. J Pediatr Endocrinol Metab 23, 507-512.

12. Lee, Y. C., Chang, C. J., Bali, D., Chen, Y. T. and Yan, Y. T. 2011. Glycogen-branching enzyme deficiency leads to abnormal cardiac development: novel insights into glycogen storage disease IV. Hum Mol Genet 20, 455-465.

13. Njølstad, P. R., Sagen, J. V., Bjørkhaug, L., Odili, S., Shehadeh, N., Bakry, D., Sarici, S. U., Alpay, F., Molnes, J., Molven, A., Søvik, O. and Matschinsky, F. M. 2003.
Permanent neonatal diabetes caused by glucokinase deficiency: inborn error of the glucose-insulin signaling pathway. Diabetes 52, 2854-2860.

14. Rosa, R., George, C., Fardeau, M., Calvin, M. C., Rapin, M. and Rosa, J. 1982. A new case of phosphoglycerate kinase deficiency: PGK Creteil associated with rhabdomyolysis and lacking hemolytic anemia. Blood 60, 84-91.

15. Servidei, S. and DiMauro, S. 1989. Disorders of glycogen metabolism of muscle. Neurol Clin 7, 159-178.

16. Shaulian, E. and Karin, M. 2001. AP-1 in cell proliferation and survival. Oncogene 20, 2390-2400.

17. Shaulian, E. and Karin, M. 2002. AP-1 as a regulator of cell life and death. Nat Cell Biol 4, 131-136.

18. Wiese, S., Schliess, F. and Haussinger, D. 1998. Osmotic regulation of MAP-kinase activities and gene expression in H4IIE rat hepatoma cells. Biol Chem 379, 667-671.

\section{초록 : 당 생합성 효소 PGK 유전자 프로모터 변이와 물렁증 저항성 멍게의 선별}

\section{조현국 ${ }^{1}$ 허영백 ${ }^{2}$ 정재훈 ${ }^{3}$ *}

( ${ }^{1}$ 국립수산과학원 생명공학연구소, ${ }^{2}$ 남해수산연구소 양식환경연구센터, ${ }^{3}$ 부산대학교 분자생물학과)

멍게의 물렁증 발병으로 인해 멍게 양식에 커다란 타격을 받고 있는 가운데 물렁증 발병에 대한 분자적인 접근 을 위해 정상 멍게와 물렁증 걸린 멍게에서 DEG 법을 수행하였다. 이번 연구에서 멍게의 당 생합성 효소인 PGK 가 물렁증에 걸린 멍게 개체에서 발현이 감소하는 것을 다양한 실험을 통해서 확인하였다. PGK에 대한 유전자 서열을 확보함과 동시에 이 유전자의 발현에 영향을 미치는 부위인 프로모터를 클로닝 하였다. 프로모터 부위의 단일 염기 다형성 분석을 통해서 -106과 -254 위치의 염기에서 다형성이 일어나는 것을 확인하였다. 물렁증에 대 한 저항성을 가진 멍게와 다른 개체군의 멍게와의 염기서열을 비교한 결과 많은 차이가 나타남을 확인하였다. 이러한 염기의 차이가 PGK의 발현에 영향을 미치는 지 확인하기 위해서 각각의 멍게 개체군에서 genomic DNA 와 total RNA를 분리하여 genotyping과 RT-PCR을 수행하였다. 그 결과 -106과 -254 위치의 염기가 AA와 GT인 개체에서 PGK의 발현량이 상대적으로 많은 것을 확인할 수 있었다. 이러한 결과는 물렁증에 대한 저항성을 가진 멍게를 선발육종하기 위한 분자적인 마커의 개발에 활용됨으로써 물렁증 발병을 줄일 수 있음을 시사하였다. 